UDC 581.552

LBC 28.58

\title{
STUDY OF THE PECULIARITIES OF THE COENOPOPULATION OF HALOCNEMUM STROBILACEUM (PALL.) BIEB. IN VOLGOGRAD REGION
}

\author{
Tatiana E. Zenkina \\ LLC "Volgogradnefteproekt", Volgograd, Russian Federation; \\ Volgograd State University, Volgograd, Russian Federation \\ Victoria O. Butenko \\ Volgograd State University, Volgograd, Russian Federation \\ Anastasia D. Bushueva \\ Volgograd State University, Volgograd, Russian Federation \\ Vadim A. Sagalaev \\ Volgograd State University, Volgograd, Russian Federation
}

\begin{abstract}
Halocnemumstrobilaceum (Pall.) Bib. is a perennial grayish-green subshrub. The plant has rooting branches, which forms curtines up to two meters and belongs to salt-accumulating hypergalophytes. H. strobilaceum dominates desert and desert-steppe communities. Its cenopopulations spatial structure and ontogenetic composition can be used for analyzing the state of phytocenosis in general, but also for identifying features of living conditions. For example, H. strobilaceum is an indicator of gas and oil content (plant in this case is in a state of dwarfism and depression under conditions of high bituminosity), groundwater in the desert (thickets are formed), water body salinization, but primarily it's used as a permanent indicator of saline soils, because its development optimal is higher than $0.6-1.0 \%$. Ecological scales is one of those methods, which used to characterize the phytoindication properties of species coenopopulations. This study contains the investigation results of the cenopopulation of $H$. strobilaceum in the territory adjacent to the VAO "Himprom", Kirov district, Volgograd city. The cenopopulation was characterized by such factors as soil moisture and acidity, cryoclimatic, thermoclimatic, salt regime, continental and arid climate, soil i moisture variability, illumination / shading. Others research methods included Ripley's function and local density map. The study found that $H$. strobilaceumcenopopulation was aging and had a random spatial pattern, which * indicates natural, stable living conditions, which means that it occupied its fundamental ecological niche. Under these conditions, the species is stenovalent to such parameters as illumination / shading, soil moisture variability and soil acidity. Therefore, H. strobilaceum can be used as a phytoindicator of the habitat by the above characteristics.

Key words: cenopopulation, Halocnemumstrobilaceum, phytoindication, ecological scales, age states, Ripley's function, local density map.

УДК: 581.552

ББК: 28.58
\end{abstract}

\section{ИССЛЕДОВАНИЕ ОСОБЕННОСТЕЙ ЦЕНОПОПУЛЯЦИИ САРСАЗАНА ШИШКОВАТОГО [HALOCNEMUM STROBILACEUM (PALL.) BIEВ.] НА ТЕРРИТОРИИ ВОЛГОГРАДСКОЙ ОБЛАСТИ}

\author{
Татьяна Евгеньевна Зенкина
}

ООО «Волгограднефтепроект», г. Волгоград, Российская Федерация; Волгоградский государственный университет, г. Волгоград, Российская Федерация 


\section{Виктория Олеговна Бутенко}

Волгоградский государственный университет, г. Волгоград, Российская Федерация

\section{Анастасия Дмитриевна Бушуева}

Волгоградский государственный университет, г. Волгоград, Российская Федерация

\section{Вадим Александрович Сагалаев}

Волгоградский государственный университет, г. Волгоград, Российская Федерация

Аннотация. В статье охарактеризованы эколого-биологические особенности сарсазана шишковатого [Halocnemumstrobilaceum (Pall.) Bieb], являющегося доминантом пустынных и пустынно-степных сообществ. Приводятся результаты исследования ценопопуляции Н. strobilaceum на территории, прилегающей к ВОАО «Химпром», Кировского района, города Волгограда. В соответствии с экологическими амплитудными шкалами Д.Н. Цыганова выявлено, что сарсазан шишковатый является фитоиндикатором среды обитания по таким параметрам, как освещенность / затенение, переменность увлажнения и кислотность почв. Изучены возрастные особенности описываемой ценопопуляции, в том числе онтогенетические состояния особей. С использованием современных математических методов, включающих расчет функции Рипли, составление карты локальной плотности при помощи метода бегущего (скользящего) окна (movingwindow), основанного на ядерных функциях kernel (kernelfunction) описана пространственная структура сообщества. Исследуемая ценопопуляция является стареющей, особи сарсазана представлены только старыми генеративными и субсенильными возрастными состояниями. Растения расположены случайным образом, что свидетельствует о благоприятной среде обитания для данного вида.

Ключевые слова: ценопопуляция, Halocnemum strobilaceum, фитоиндикация, экологические шкалы, возрастные состояния, функция Рипли, карта локальной плотности.

Сарсазан шишковатый [Halocnemum strobilaceum (Pall.) Bieb.] - многолетний полукустарник или невысокий полукустарничек серовато-зеленого цвета, который имеет укореняющиеся ветви, образует куртины до 2 метров и относится к соленакапливающим гипергалофитам $[1 ; 11 ; 14 ; 16]$. Для сарсазана шишковатого характерны цилиндрические, сочные, прямостоячие, деревянистые побеги с супротивно расположенными листьями, которые имеют вид чешуек. Семена сжатые, буроватого цвета и имеют пузырчатый край. Цветение и плодоношение сарсазана происходит в августе-сентябре. Чаще всего встречается по мокрым и пухлым солончакам, берегам соленых озер, сорам. Встречается в степном полупустынном Казахстане $[1 ; 7 ; 10$; $11 ; 18 ; 22]$.

Внесен в Красные книги Омской и Новосибирской областей $[13 ; 14]$. Сарсазан шишковатый содержит алкалоиды (до 0,5 \% в молодых побегах), щелочные соли, сапонины, поэтому вид используется в медицине, фитомелиорации засоленных почв, является инсектицидным средством, а также осенне-зимним кормом для скота [3]. Помимо этого, H. strobilaceum - индикатор содержания газа и нефти, поскольку в условиях повышенной битуминозности он находится в состоянии карликовости и угнетенности [12].

В случае осолонения водоем среди тростника появляются пятна сарсазана. Наличие H. strobilaceum в солончаковых пустынях в виде прижатых к субстрату плоских куртин говорит о хлоридном засолении. Если растение приподнимается над землей, то для этой местности характерно преобладание сульфата кальция, а хлоридное засоление непостоянно [4].

Сарсазан является индикатором подземных вод в пустыне: поскольку в зоне разгрузки линз подземных вод она испаряется и выходят соли, такой участок покрыт зарослями сарсазана. Также $H$. strobilaceum используется как постоянный индикатор засоленных почв, так как является облигатным галофитом, чей оптимум развития в случае засоления почв выше 0,6-1,0 \% [18].

Поскольку H. strobilaceum выполняет роль доминанта пустынных и пустынно-степных сообществ. По характеру пространственной структуры и онтогенетическому составу его ценопопуляций можно проанализировать состояние фитоценоза в целом, а также выя- 
вить особенности условий обитания. Одним из методов, используемых для характеристики фитоиндикационных свойств ценопопуляций видов являются экологические шкалы.

\section{Материалы и методы}

Цель работы - изучить пространственно-онтогенетические и фитоиндикационные особенности ценопопуляции сарсазана шишковатого (Halocnemum strobilaceum (Pall.) Bieb.) расположенной на территории Волгоградской области. Исследования проводились осенью 2017 года в окрестностях ВОАО «Химпром» (рис. 1) Кировского района, города Волгограда.

Изучаемая территория представлена светло-каштановыми и супесчаными почвами с наличием солончаков $[5 ; 6]$.

В описываемом сообществе располагались только особи сарсазана. При определении размера пробной площадки использовалось понятие элементарной демографической единицы ценопопуляции (ЭДЕ) $[17 ; 20]$. Ранее авторами был рассчитан наибольший размер ЭДЕ сарсазана шишковатого, составляющий 19 м $^{2}$ при максимальном радиусе репродуктивной активности [9]. Размер изучаемого участка не должен быть меньше размера ЭДЕ, так для удобства картирования авторами была принята площадь равная $25 \mathrm{M}^{2}$.
В ходе работ были установлены численность, плотность, возрастной состав и пространственная структура исследуемой ценопопуляции сарсазана $[2 ; 8 ; 9]$.

Пространственное расположение особей оценивалось современными математическими методами $[15 ; 19 ; 21]$. Был произведен расчет $K(r)$ функции Рипли [26; 27], составлена карта локальной плотности при помощи метода бегущего (скользящего) окна (moving window) [24], который основан на ядерных функциях kernel (kernel function) [28; 29]. Полученный результат представлен графически в виде функции $L(r)-r$, где $L(r)=\sqrt{ } K(r) / \pi$ [25] для более удобного анализа.

Изучение фитоиндикационных свойств H. strobilaceum проводилось с помощью экологических шкал. В исследовании использовались амплитудные шкалы Д.Н. Цыганова, включающие в себя 10 экологических факторов. Каждый из факторов имеет определенное количество ступеней. Количественная характеристика того, как вид использует определенный экологический фактор, называется экологической валентностью. В данной работе описывалась потенциальная экологическая валентность (PEV). В зависимости от значения потенциальной экологической валентности растение определяют в следующие фракции:

- стеновалентная (CB) - PEV $\leq 0,33$;

- гемистеновалентная (ГСВ) $-\mathrm{PEV}=$ $0,34-0,45$;

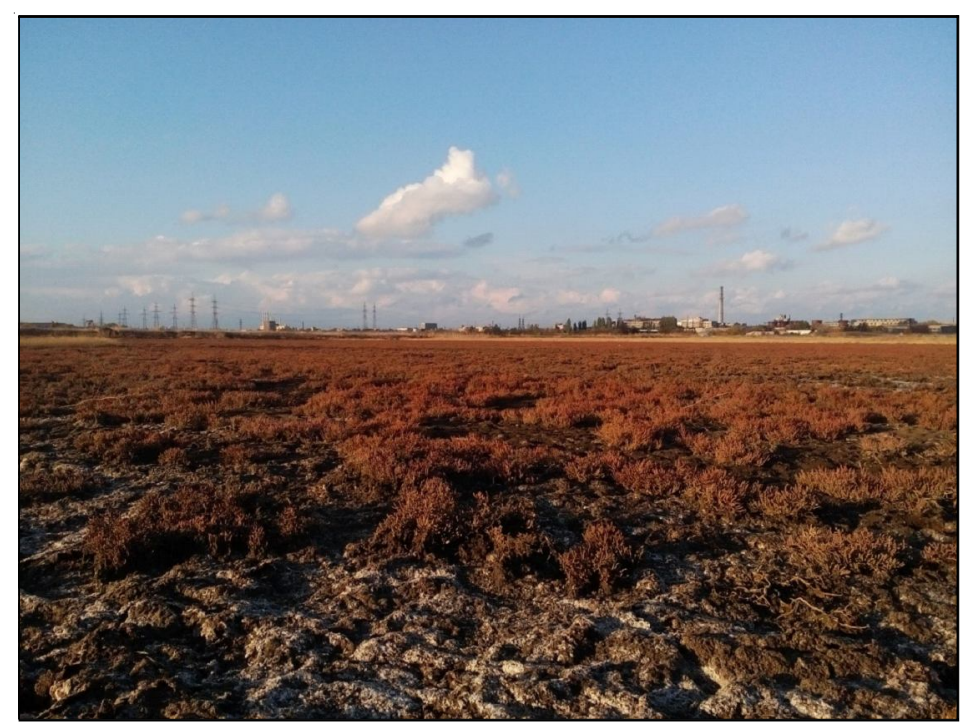

Рис. 1. Сарсазановое сообщество, находящееся на исследуемой территории 
- мезовалентная (MB) - PEV =0,46-0,56;

- гемиэвривалентная (ГЭВ) - $\mathrm{PEV}=$ 0,57-0,66;

- эвривалентная (ЭВ) - $\mathrm{PEV} \geq 0,67$.

Популяция конкретного вида способна занимать разнообразные экологически местообитания в случае, если показатель валентности высокий, и имеет более ограниченный выбор, если показатель валентности низкий [23].

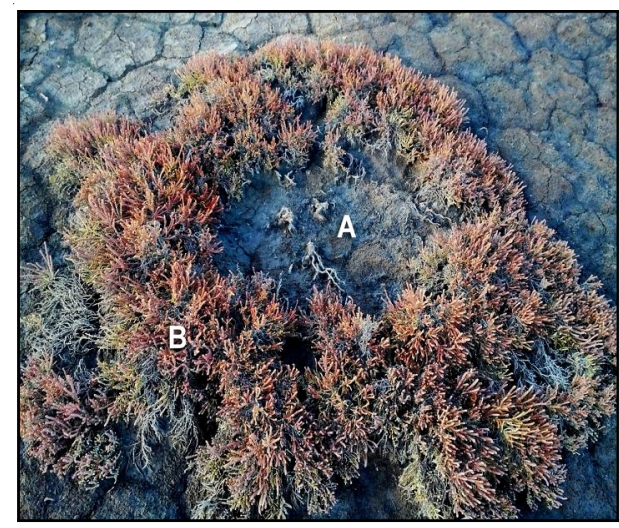

Рис. 2. Куртина H. strobilaceum $g_{3}$ возрастного состояния: A - отмирание побегов в центре куртины; В - укоренившиеся партикулы с вегетативными и генеративными побегами

\section{Результаты исследования}

Всего на исследуемой площадке было отмечено 50 особей $H$. strobilaceum, $45 \%$ из которых относились к старым генеративным, а $55 \%$ - к субсенильным возрастным состояниям (рис. 2-4). Согласно классификации, основанной на определении критерия абсолютного максимума исследуемая ценопопуляция является стареющей [8].

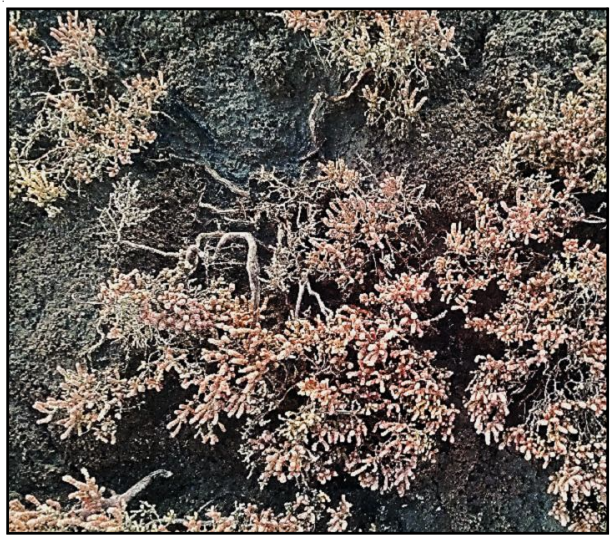

Рис. 3. Куртина H. strobilaceum ss возрастного состояния: центральная часть куста разрушается, а на старых партикулах формируются исключительно вегетативные побеги

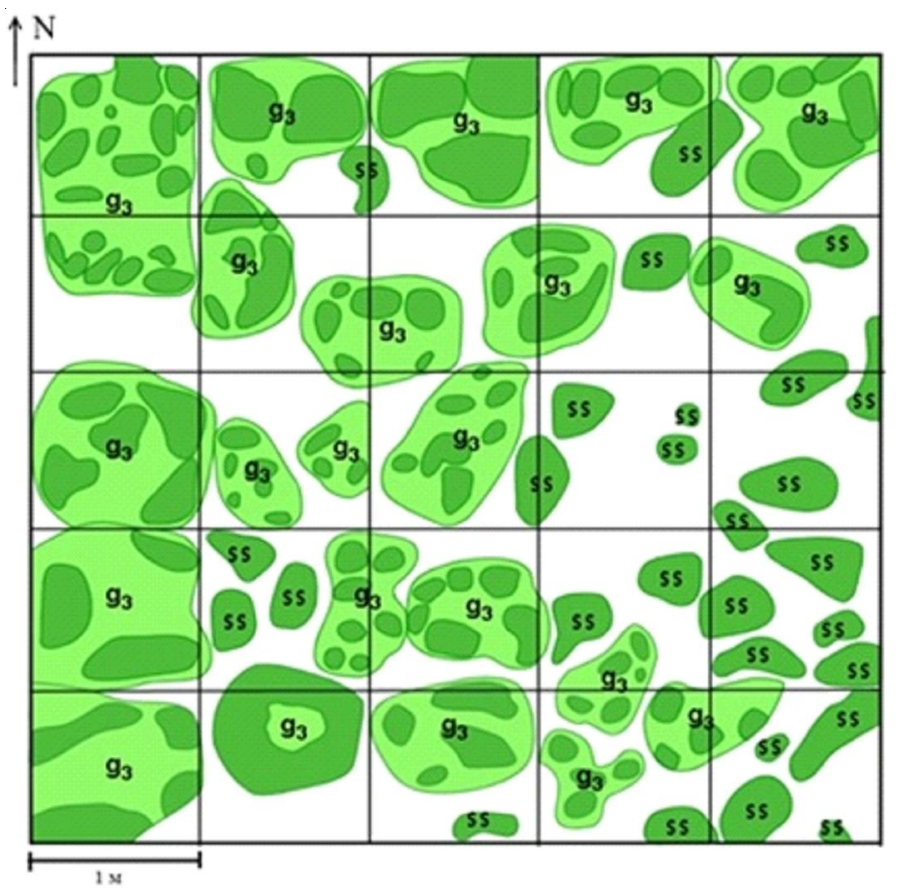

Рис. 4. Схема закартированной площадки сарсазанового сообщества:

$g_{3}$ - генеративное возрастное состояние; $s s-$ субсенильное возрастное состояние 


\section{БИОЛОГИЯ И БИОТЕХНОЛОГИЯ}

При оценке пространственного размещения сарсазана с помощью ядерной функции выявлено, что плотность составила 2-4,5 особи/м² (рис. 5). С помощью графической интерпретации функции Рипли было установлено, что в данной ценопопуляции растения дистанцируются друг от друга на расстояние $0,3-$ 0,6 м, и далее располагаются случайным образом с некоторой тенденцией к группированию (рис. 6). Данный пространственный узор обусловлен тем, что в левой части площадки расположено больше старых генеративных растений, куртины которых достигают в диаметре до 1 м и не перекрываются друг с другом, что может быть обусловлено механизмами внутривидовой конкуренции. В правом нижнем углу площадки преобладают сенильные особи более мелкого размера, что позволяет большему количеству особей разместиться на исследуемой территории.

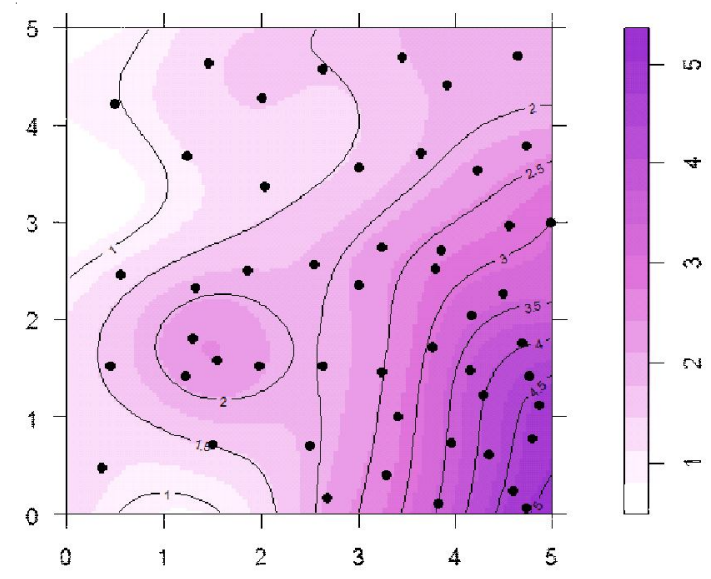

Рис. 5. Карта-схема локальной плотности ЦП Halocnemum strobilaceum
Пространственный узор ценопопуляции вида является диагностическим признаком условий его обитания, так случайное размещение особей говорит о наличии благоприятной среды, позволяющей растениям размещаться в комфортном режиме [9].

В ходе исследований было установлено, что ценопопуляция сарсазана на территории, прилегающей к ВОАО «Химпром» занимает нишу близкую к фундаментальной, поскольку было отмечено отсутствие сопутствующих или содоминантных видов, а значит $H$. strobilaceum может полностью реализовать механизмы освоения пространства.

На основе полученных данных, а также амплитудной шкалы Д.Н. Цыганова была построена диаграмма, отражающая пределы толерантности исследуемого вида (рис. 7). На графике видно, что H. strobilaceum по некоторым параметрам, таким как: освещенность /

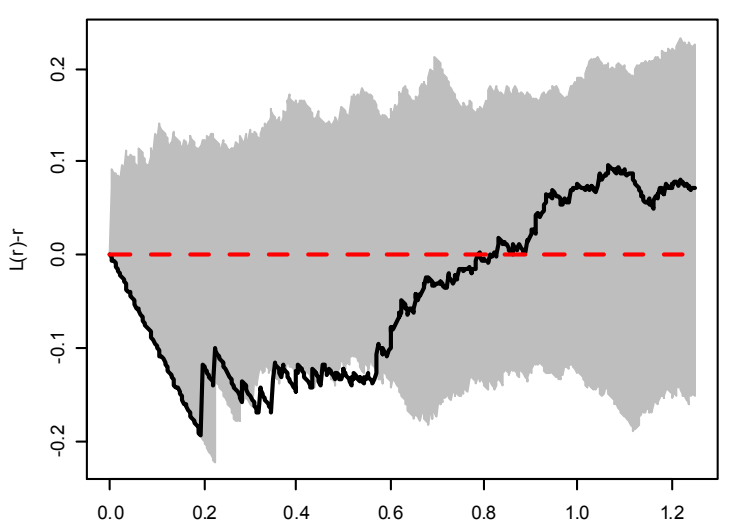

Рис. 6. Поведение функцй Рипли для особей Halocnemum strobilaceum

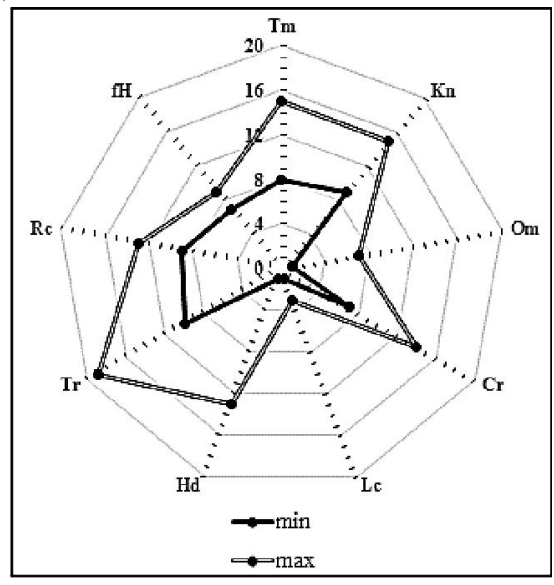

Рис. 7. Пределы толерантности Halocnemum strobilaceum 
затенение (LC), переменность увлажнения почв $(\mathrm{FH})$, кислотность почв (RC), характеризуется Узкой экологической амплитудой - промежуток между максимумом и минимумом отдельных экологических факторов не превышает 510 ступеней (рис. 7). Варианты местообитаний, которые может занимать вид по данным параметрам крайне ограничен, следовательно, сарсазан можно использовать как индикатор по вышеуказанным характеристикам.

По увлажненности почв (HD) экологическая амплитуда имеет более широкий диапазон (рис. 7). Так, сарсазан хорошо развивается на освещенных территориях, может обитать на засушливых и сильно увлажненных участках, но плохо переносит смену увлажнения почв, которая приводит к гибели прегенеративных особей.

Согласно экологическим шкалам было установлено, что $H$. strobilaceum является гемиэвривалентным видом по отношению к фактору увлажнения почв. По большей части, исследуемых параметров сарсазан характеризуется как мезовалентный вид: по отношению к термоклиматическому, криоклиматическому факторам, а также к факторам солевого режима, континентальности и аридности климата. Исследуемый вид гемистеновалентен по отношению к фактору кислотности почв и стеновалентен по отношению к факторам освещенности и переменности увлажнения почв (см. таблицу).

Индекс толерантности H. strobilaceum составляет 0,56 , что позволяет отнести его к мезобионтным видам.

Таким образом, изучение пространственно-онтогенетической структуры цено- популяции вида и исследование его особенностей с применением экологических шкал позволило оценить возможность использования Halocnemum strobilaceum в качестве фитоиндикатора условий обитания.

\section{Заключение}

1. В ходе работ было установлено, что на территории, прилегающей к $\mathrm{BOAO}$ «Химпром», Кировского района, города Волгограда исследуемая ценопопуляция $H$. strobilaceum является стареющей и обладает случайным пространственным узором, что говорит о естественных, стабильных условиях обитания.

2. Изучаемая ценопопуляция сарсазана шишковатого заняла свою фундаментальную экологическую нишу, в условиях которой вид является стеновалентным по таким параметрам как: освещенность / затенение, переменность увлажнения почв, кислотность почв. Следовательно, H. strobilaceum можно охарактеризовать как фитоиндикатор среды обитания по вышеуказанным признакам.

\section{СПИСОК ЛИТЕРАТУРЫ}

1. Акжигитова, Н. И. Галофитная растительность Средней Азии и ее индикационные свойства / Н. И. Акжигитова. - Ташкент : Фан, 1982. - 190 с.

2. Василевич, В. И. Статистические методы в геоботанике / В. И. Василевич. - Л. : Наука, 1969. $232 \mathrm{c}$.

3. Васина, А. Н. Использование растений диких видов для борьбы с вредителями садовых и овощных культур / А. Н. Васина. - М. : Колос, 1972. - 58 с.

Характеристика Halocnemum strobilaceum по экологическим шкалам

\begin{tabular}{|l|c|c|c|c|}
\hline \multicolumn{2}{|c|}{ Тип шкалы по факторам } & $\begin{array}{c}\text { Диапазон } \\
\text { шкалы }\end{array}$ & $\begin{array}{c}\text { Потенциальная } \\
\text { экологическая } \\
\text { валентность } \\
\text { (РЕV) }\end{array}$ & Фракция валентности \\
\hline Увлажнения почв & $\mathrm{HD}$ & $1-13$ & 0,57 & Гемиэвривалентная \\
\hline Солевого режима & $\mathrm{TR}$ & $10-19$ & 0,53 & Мезовалентная \\
\hline Термоклиматическая & $\mathrm{TM}$ & $8-15$ & 0,47 & Мезовалентная \\
\hline Континентальности климата & $\mathrm{KN}$ & $9-15$ & 0,47 & Мезовалентная \\
\hline Аридности / гумидности климата & $\mathrm{OM}$ & $1-7$ & 0,47 & Мезовалентная \\
\hline Криоклиматическая & $\mathrm{CR}$ & $7-14$ & 0,53 & Мезовалентная \\
\hline Кислотности почв & $\mathrm{RC}$ & $9-13$ & 0,38 & Гемистеновалентная \\
\hline Освещенности / затенения & $\mathrm{LC}$ & $1-3$ & 0,33 & Стеновалентная \\
\hline Переменности увлажнения почв & $\mathrm{FH}$ & $7-9$ & 0,27 & Стеновалентная \\
\hline
\end{tabular}


4. Викторов, С. В. Индикационная геоботаника : учеб. пособие / С. В. Викторов, Г. Л. Ремезова. -М. : Изд-во Моск. ун-та, 1988. - 168 с.

5. География и экология Волгоградской области : учеб. пособие для ср. шк. -2-е изд., перераб. и доп. / авт. кол.; под общ. ред. проф. В. А. Брылева. Волгоград : Перемена, 2005. - 260 с.

6. Государственный доклад «О состоянии санитарно-эпидемиологического благополучия населения в Волгоградской области в 2015 году» / Управление Федеральной службы по надзору в сфере защиты прав потребителей и благополучия человека по Волгоградской области. - Волгоград, 2015. - 314 с.

7. Жукова, Л. А. Онтогенетический атлас растений : науч. изд. Т. VII / отв. и науч. ред. проф. JI. А. Жукова. - Йошкар-Ола : Мар. гос. ун-т, 2013. -364 c.

8. Жукова, Л. А. Популяционная жизнь луговых растений / Л. А. Жукова. - Йошкар-Ола : Ланар, 1995. - 224 c.

9. Зенкина, Т. Е. Исследование ценопопуляций видов-доминантов галофитных сообществ в Кумо-Манычской впадине (Республика Калмыкия) : автореф. дис. ... канд. биол. наук / Зенкина Татьяна Евгеньевна. - Тольятти, 2016. - 20 с.

10. Зенкина, Т. Е. Особенности онтогенеза Сарсазана шишковатого [Halocnemum strobilaceum (Pall.) Bieb., Chenopodiaceae] в условиях Нижнего Поволжья / Т. Е. Зенкина // Современные проблемы географии, экологии и природопользования : материалы Междунар. науч. конф. (г. Волгоград, 2224 апреля 2012 г.). - Волгоград : Изд-во ВолГУ, 2012. C. $56-58$.

11. Зенкина, Т. Е. Пространственная и демографическая структура ценопопуляций Сарсазана шишковатого (Halocnemum strobilaceum (Pall.) Bieb., Chenopodiaceae) в Республике Калмыкии / Т. Е. Зенкина, В. А. Сагалаев // Вестник ВолГУ. Серия 11, Естественные науки. - 2012. - № 1 (3). - С. 10-17.

12. Каплин, В. Г. Биоиндикация состояния экосистем : учеб. пособие для студентов биол. специальностей ун-тов и с.-х. вузов / В. Г. Каплин. - Самара : Самар. гос. с.-х. акад., 2001. - 143 с.

13. Красная книга Новосибирской области: Животные, растения и грибы. - Новосибирск : Арта, 2008. - 527 с.

14. Красная книга Омской области / отв. ред. Г. Н. Сидоров, В. Н. Русаков. - Омск : ОмГПУ, 2006. $460 \mathrm{c}$.

15. Математические подходы к анализу пространственно-возрастной структуры популяций дерновинных видов трав / М. Б. Фардеева [и др.] // Экология. - 2009. - № 4. - С. 249-257.

16. Прозорова, Т. А. Кормовые растения Казахстана / Т. А. Прозорова, И. Б. Черных. - Павлодар : Павлодар. гос. ун-т, 2004. - 278 с.
17. Смирнова, О. В. Популяционная организация биоценотического покрова лесных ландшафтов / О. В. Смирнова // Успехи совр. Биол. - 1998. T. 2. - C. 25-39.

18. Туровцев, В. Д. Биоиндикация : учеб. пособие / В. Д. Туровцев, В. С. Краснов - Тверь : Твер. гос. ун-т., 2004. -260 с.

19. Фардеева, М. Б. К изучению пространственной структуры черники (Vaccinium myrtillus L.) / М. Б. Фардеева, Г. Р. Исламова // Окружающая среда и устойчивое развитие регионов: новые методы и технологии исследований : тр. всерос. конф. с междунар. участием. - Казань : Отечество, 2009. C. 307-312.

20. Фардеева, М. Б. Многолетняя динамика пространственно-временной структуры популяций Orchis militaris L. (Orchidaceae Juss.) / М. Б. Фардеева // Известия Самар. науч. центра РАН. - 2013. T. 15, № 3 (1). - С. 352-357.

21. Фардеева, М. Б. Многолетняя динамика онтогенетической и пространственной структуры ценопопуляций Cypripedium calceolus L. / М. Б. Фардеева, Н. А. Чижикова, О. В. Красильникова // Ученые записки Казан. гос. ун-та. Сер.: Естественные науки. - 2010. - Т. 152, кн. 3. - С. 159-173.

22. Флора СССР / глав. ред. акад. В. Л. Комаров. - Ленинград : Изд-во акад. наук СССР, 1936. T. $6 .-956 \mathrm{c}$.

23. Экологические шкалы и методы анализа экологического разнообразия растений : монография / Л. А. Жукова [и др.]; под общ. ред. проф. Л. А. Жуковой. - Йошкар-Ола : Мар. гос. ун-т, 2010. - 368 с.

24. Bailey, T. C. Interactive Spatial Data Analysis / T. C. Bailey, A. Gatrell. - Harlow, England : Longman Scientific \& Technical, 1995. - 413 p.

25. Besag J. Contribution to the Discussion of Dr Ripley's Paper / J. Besag // Journal of the Royal Statistical Society, Series B. - 1977. - № 39. - P. 193-195.

26. Ripley, B. D. Modelling Spatial Patterns / B. D. Ripley // Journal of the Royal Statistical Society, Series B. - 1977. - № 39. - P. 172-212.

27. Ripley, B. D. The Second-Order Analysis of Stationary Point Processes / B. D. Ripley // Journal of Applied Probability. - 1976. - № 13. - P. 255-266.

28. Scott, D. W. Multivariate Density Estimation. Theory, Practice and Visualization / D. W. Scott. N. Y. : John Wiley \& Sons Ltd, 1992. - 384 p.

29. Silverman, B. W. Density Estimation for Statistics and Data Analysis / B. W. Silverman. - L. : Chapman and Hall, 1986. - 175 p.

\section{REFERENCES}

1. Akzhigitova N.I. Galofitnaja rastitelnost Srednej Azii i ejo indikacionnye svojstva [Halophytic 
Vegetation of Central Asia and its Indicative Properties]. Tashkent, Fan Publ., 1982. 190 p.

2. Vasilevich V.I. Statisticheskie metody $v$ geobotanike [Statistical Methods in Geobotany]. Leningrad, Nauka, 1969.232 p.

3. Vasina A.N. Ispolzovanie rastenij dikih vidov dlja borby s vrediteljami sadovyh i ovoshhnyh kultur [The Use of Wild Plants for Pest Control of Garden and Vegetable Crops]. Moscow, Kolos Publ., 1972. 58 p.

4. Viktorov S.V., Remezova G.L. Indikacionnaja geobotanika: ucheb. posobie [Indicative Geobotany: Training Manual]. Moscow, Moscow University Publ., $1988.168 \mathrm{p}$.

5. Geografija i jekologija Volgogradskoj oblasti: ucheb. posobie dlja sr. shk (2-e izd.) [Geography and Ecology of the Volgograd Region: a Textbook for Middle School (2 ${ }^{\text {nd }}$ ed.)]. V. A. Brylev (eds.). Volgograd, Peremena Publ., 2005. 260 p.

6. Gosudarstvennyj doklad «O sostojanii sanitarno-jepidemiologicheskogo blagopoluchija naselenija v Volgogradskoj oblasti v 2015 godu» [State Report "On the State of Sanitary and Epidemiological Welfare of the Population in the Volgograd Region in 2015"]. Upravlenie Federalnoj sluzhby po nadzoruv sfere zashhity prav potrebitelej $i$ blagopoluchija cheloveka po Volgogradskoj oblasti [Department of the Federal service for supervision of consumer rights protection and human welfare in the Volgograd region]. $2015.314 \mathrm{p}$.

7. Zhukova L.A. Ontogeneticheskij atlas rastenij: nauchnoe izdanie [Ontogenetic Atlas of Plants: a Scientific Publication]. Mar. St. Univ. YoshkarOla, 2013, vol. 8, 364 p.

8. Zhukova L.A. Populjacionnaja zhizn lugovyh rastenij [Population Life of Meadow Plants]. Lanar Yoshkar-Ola, 1995. 224 p.

9. Zenkina T.E. Issledovanie cenopopuljacij vidov-dominantov galofitnyh soobshhestv v KumoManychskoj vpadine (Respublika Kalmykija). Avtoref. dis. kand. biol. nauk [The Study of Populations of Dominant Species of Halophytic Communities in the Kuma-Manych Depression (Republic of Kalmykia). Abst. of cand. bio. sci. diss.]. Togliatti, 2016. 20 p.

10. Zenkina T.E. Osobennosti ontogeneza Sarsazana shishkovatogo [Halocnemum Strobilaceum (Pall.) Bieb., Chenopodiaceae] v uslovijah Nizhnego Povolzh'ja [Features of ontogenesis of Halocnemum strobilaceum (Pall.) Bieb. (Chenopodiaceae) in the Lower Volga region]. Sovremennye problemy geografii, jekologii $i$ prirodopolzovanija: materialy mezhdunarodnoj nauchnoj konferencii (g. Volgograd, 22-24 aprelja 2012 g.) [Modern Problems of Geography, Ecology and Nature Management: Materials of the International Scientific Conference, Volgograd, April 22-24, 2012]. Volgograd, VolSU Publ., 2012, pp. 56-58.
11. Zenkina T.E., Sagalaev V.A. Prostranstvennaja i demograficheskaja struktura cenopopuljacij Sarsazana shishkovatogo (Halocnemum strobilaceum (Pall.) Bieb., Chenopodiaceae) v Respublike Kalmykii [Regional and Demographical Structure of Cenopopulations of Halocnemum strobilaceum (Pall.) Bieb. (Chenopodiaceae) in the Republic of Kalmykia]. Vestnik VolGU. Seriya 11 [Bull. of the VolSU. Series 11], 2012, no. 1 (3), pp. 10-17.

12. Kaplin V.G. Bioindikacija sostojanija jekosistem: ucheb. posobie dlja studentov biol. special'nostej un-tov i s.-h. vuzov [Bioindication of the State of Ecosystems: a Textbook for Students of Biol. Specialties and Agricultural Universities]. Samara, 2001. 143 p.

13. Krasnaja kniga Novosibirskoj oblasti: Zhivotnye, rastenija i griby [The Red Book of the Novosibirsk Region: Animals, Plants and Mushrooms]. Novosibirsk, Arta, 2008. 527 p.

14. Krasnaja kniga Omskoj oblasti [The Red Book of the Omsk Region]. G.N. Sidorov, V.N. Rusakov (eds.). Omsk, OmGPU, 2006. 460 p.

15. Fradeeva M.B., Chizhikova N.A., Birjuchevskaja N.V., et al. Matematicheskie podhody $\mathrm{k}$ analizu prostranstvenno-vozrastnoj struktury populjacij dernovinnyh vidov trav [Mathematical Approaches to the Analysis of the Spatial and Age Structure of Populations of Turf Grass Species]. Jekologija [Ecology], 2009, no. 4, pp. 249-257.

16. Prozorova T.A., Chernych I.B. Kormovye rastenija Kazahstana [Kazakhstan Fodder Plants]. Pavlodar, Pavlodar. gos. un-t, 2004. 278 p.

17. Smirnova O.V. Populjacionnaja organizacija biocenoticheskogo pokrova lesnyh landshaftov [The Population Organization of the Biocenotic Cover of Forest Landscapes]. Uspehi sovr. Biol. [Advances in Modern Biology], 1998, vol. 2, pp. 25-39.

18. Turovcev V.D., Krasnov V.S. Bioindikacija: uchebnoe posobie [Bioindication: a Training Manual]. Tver, Tver. gos. un-t, 2004. 260 p.

19. Fardeeva M.B., Islamova G.R. K izucheniju prostranstvennoj struktury cherniki (Vaccinium myrtillus L.) [To the Study of the Spatial Structure of Blueberries (Vaccinium myrtillus L.)]. Okruzhajushhaja sreda $i$ ustojchivoe razvitie regionov: novye metody i tehnologii issledovanij: Tr. Vseros. konf. s mezhd. uch. [Environment and Sustainable Development of Regions: New Research Methods and Technologies: Th. all-Rus. Conf. with Int. Part.]. Kazan, Otechestvo, 2009, pp. 307-312.

20. Fardeeva M.B. Mnogoletnjaja dinamika prostranstvenno-vremennoj struktury populjacij Orchis militaris L. (Orchidaceae Juss.) [Long-Term Dynamics of the Spatiotemporal Structure of the Populations of Orchis militaris L. (Orchidaceae Juss.)]. Izvestija Samarskogo nauchnogo centra 
$R A N$ [Bull. of the Samara Scientific Center of the Russian Academy of Sciences], 2013, vol. 15, no. 3 (1), pp. 352-357.

21. Fardeeva M.B., Chizhikova N.A., Krasil'nikova O.V. Mnogoletnjaja dinamika ontogeneticheskoj i prostranstvennoj struktury cenopopuljacij Cypripedium calceolus L. [Long-Term Dynamics of the Ontogenetic and Spatial Structure of Cypripedium calceolus L. cenopopulations]. Uchenye zapiski Kazanskogo gos. un-ta. Serija: Estestv. Nauki [Scientific notes of the Kazan St. Univ. Series: Natural Science]. 2010, vol. 152, b. 3, pp. 159-173.

22. Flora SSSR [Flora of the USSR]. V.L. Komarov, B.K. Shishkin (eds.). Leningrad, The Academy of Sciences of the USSR Publ. 1936, vol.6, $956 \mathrm{p}$.

23. Jekologicheskie shkaly $i$ metody analiza jekologicheskogo raznoobrazija rastenij: monografija [Ecological Scales and Methods for Analyzing the Ecological Diversity of Plants:
Monograph]. L.A. Zhukovoj (eds.). Yoshkar-Ola, Mar. St. Univ., 2010. 368 p.

24. Bailey T.C., Gatrell A. Interactive Spatial Data Analysis. Harlow, England, Longman Scientific \& Technical, 1995. $413 \mathrm{p}$.

25. Besag, J. Contribution to the Discussion of Dr Ripley's Paper. Journal of the Royal Statistical Society, Series B. 1977, no. 39, pp. 193-195.

26. Ripley B.D. Modelling Spatial Patterns. Journal of the Royal Statistical Society, Series B, 1977, no. 39, pp. 172-212.

27. Ripley B.D. The Second-Order Analysis of Stationary Point Processes. Journal of Applied Probability. 1976, no. 13, pp. 255-266.

28. Scott D.W. Multivariate Density Estimation. Theory, Practice and Visualization. New-York, John Wiley \& Sons Ltd, 1992. 384 p.

29. Silverman B.W. Density Estimation for Statistics and Data Analysis. London, Chapman and Hall, 1986. 175 p.

\section{Information About the Authors}

Tatiana E. Zenkina,Candidate of Sciences (Biology), Senior Lecturer, Department of Biology, Volgograd State University, Prosp. Universitetsky, 100, 400062 Volgograd, Russian Federation; Head of Ecological Department, LLC “Volgogradnefteproekt”, Lesogorskaya St., 85a, 400048 Volgograd, Russian Federation, tatyanaez@mail.ru, zenkina@volsu.ru.

Victoria O. Butenko, Student,Department of Biology, Volgograd State University, Prosp. Universitetsky, 100, 400062 Volgograd, Russian Federation, msbrain27@gmail.com.

Anastasia D. Bushueva, Student,Department of Biology, Volgograd State University, Prosp. Universitetsky, 100, 400062 Volgograd, Russian Federation, anasibu24@gmail.com.

Vadim A. Sagalaev, Doctor of Sciences (Biology), Professor, Volgograd State University, Prosp. Universitetsky, 100, 400062 Volgograd, Russian Federation, alex_sag@mail.ru, bot@volsu.ru.

\section{Информация об авторах}

Татьяна Евгеньевна Зенкина, кандидат биологических наук, старший преподаватель кафедры биологии, Волгоградский государственный университет, просп. Университетский, 100, 400062 г. Волгоград, Российская Федерация; начальник отдела экологии, ООО «Волгограднефтепроект», ул. Лесогорская, 85a, 400048 г. Волгоград, Российская Федерация, tatyanaez@mail.ru, zenkina@volsu.ru.

Виктория Олеговна Бутенко, студентка кафедры биологии, Волгоградский государственный университет, просп. Университетский, 100, 400062 г. Волгоград, Российская Федерация, msbrain27@gmail.com.

Анастасия Дмитриевна Бушуева, студентка кафедры биологии, Волгоградский государственный университет, просп. Университетский, 100, 400062 г. Волгоград, Российская Федерация, anasibu24@gmail.com.

Вадим Александрович Сагалаев, доктор биологических наук, профессор, Волгоградский государственный университет, просп. Университетский, 100, 400062 г. Волгоград, Российская Федерация, alex_sag@mail.ru, bot@volsu.ru. 